the main interest was aroused in a session discussing the computer in a non-arithmetic role. Here papers were presented on language translation, the playing of games and, finally, character recognition. A contribution was made by the U.S.S.R. delegates, who have been carrying out English to Russian translation on one of their machines since early in 1955. They assured their audience that the result was good Russian.

In conclusion, it can be stated that the convention brought together a large amount of detailed and expert technical knowledge in the various aspects of digital computers and their use. There is no doubt, too, that it proved valuable in some way to all who attended. The complete proceedings of the convention, containing the addresses, lectures, full text of all papers, and reports on the discussions, will be published in three issues as a supplement to Part $B$ of the Proceedings of the Institution of Electrical Engineers.

David B. G. EDwards

\section{BRITISH AGRICULTURAL HISTORY SOCIETY}

\section{ANNUAL MEETING}

GINCE it was founded in 1953, the British Agri$\$$ cultural History Society has held its annual meeting near Easter, and this year's meeting was at the Florence Nightingale Hall, University of Nottingham, on April 13. Officially, the annual general meeting is confined to one day-a business meeting in the morning followed by one or more papers read by members, and either more papers in the afternoon, or a visit to some point of interest. In addition, however, an after-dinner lecture was given in the evening of the previous day by $\mathbf{M r}$. John W. J. Higgs, curator of the Museum of Rural Life, Reading, and also honorary secretary of the Society. His lecture, which dealt with the problems involved in the identification and preservation of agricultural exhibits, was pleasantly informal and illustrated with lantern-slides. From the pictures it was clear that it is often difficult to discern the use of an object sent in, and even more so to date it. One such question arose out of the discovery on English farms of numbers of ox-shoes, or cues. It seems quite unlikely that bullocks on a farm would ever be shod, even if they were used for draught purposes, though they might be if used on roads. The explanation is probably that the animals were shoed before being brought from distant breedingareas-Wales and Scotland, for example-and that it was not worth taking off any that remained on after the journey; eventually the shoes wore off and were dropped on the farm where the beasts were grazed. Many other similarly perplexing questions arise.

After the business meeting on April 13, the rest of the morning was occupied by two lectures, the first of which, given by Malcolm Gray, lecturer in economics in the University College of North Wales, Bangor, was on the "Consolidation of the Crofting System, 1750-1850". The story is extremely complex. Until 1815, population increased in the Western Highlands and Islands, and the number of crofts went up. Many were quite minute, only an acre or two. Attempts were made to meet the demand for land by rearranging the holdings, a kind of enclosure, but very different from the work done under Enclosure Acts in England. The kelp industry and the linen industry did a good deal to ease conditions, and the introduction of the potato was a boon. It provided more food from a given area than a grain crop. But it was attacked by disease, and the kelp industry lost ground in face of the competition of imported potash. These two factors, and a number of others, helped to make it difficult for the crofting system to survive. Dr. W. G. Hoskins, reader in economic history in the University of Oxford, gave the second lecture, which was on "Sheep Farming in Saxon England". There is only limited and scattered evidence on which to base such a lecture. A little is supplied by archæology, some by the study of place names, and some by a few documents. From these sources Dr. Hoskins has deduced the distribution of sheep in Anglo-Saxon England, and has estimated the total number as being about six million, or three or four sheep to each human being.

In the afternoon a visit was paid to the open fields at Laxton, now owned and preserved by the Government. Dr. J. D. Chambers, of the University of Nottingham, who is well known for his studies of the eighteenth century, acted as guide, and $\mathrm{Mr}$. Rose, bailiff of the Manor, showed the fields.

\section{THE PLACE OF UNIVERSITIES IN AUSTRALIA}

$T$ HE Australian Vice-Chancellors' Committee has published in pamphlet form a symposium of papers on "The Place of the Australian University in the Community and Post-Graduate Studies in the Australian Universities", which were delivered during August 11-12, 1955, at a Commonwealth InterUniversity Conference arranged in Australia by the Association of Universities of the British Commonwealth and the Australian Vice-Chancellors' Committee*. The first of these papers, by Prof. P. H. Partridge, on the Australian universities and Governments, gives a clear account of the closer dependence of Australian universities upon the State and Federal Governments, and this paper will assist those in Britain to understand some of the difficulties and dangers to which the Australian universities are exposed and also some episodes that may have puzzled those reading about them. Moreover, some of these dangers, such as that arising from the tendency in the thinking of Governments to subordinate research, advanced scholarship and postgraduate studies to the more elementary functions of making it possible for large numbers to gain degrees, could arise in Britain in appropriate circumstances ; and Prof. Partridge notes other factors, such as the absence of any considerable proportion of university-educated men among Australian politicians, which have contributed to lack of understanding of the universities or respect for their autonomy in Australia. While he thinks the existing structure may be unhealthy and dangerous, he does not think that the independence of the Austrelian universities has been affected as much as might have been expected. *Australian Vice-Chancellors' Committee. A Symposium on the
Place of the Australian University in the Community and PostPraduate Studies in the Australian Universities. Pp. B6. (Canberra: Australian Vice-Chancellors' Committee, c/o Australian National Committee. Londo 
Prof. Partridge, moreover, offers some wise counsel to the universities which has relevance even in the more favourable circumstances of Britain. He suggests that, in spite of obvious dangers and difficulties, the universities should, in partnership with the Commonwealth and State Governments, attempt to evolve national policies of expansion and policies which will provide for some measure of specialization in the different universities, particularly in research. It is not unreasonable, he argues, to expect that the universities should at least explore the possibility of using as rationally as possible the greater resources placed at their disposal by the State, and there is much to be gained from the point of view of academic standards by not dispersing available workers too thinly over a comparatively large number of institutions. To take the initiative in such ways would, he believes, strengthen the universities themselves and might also facilitate the change in thinking of the State Governments which he also thinks desirable for the use of Commonwealth funds and to meet national needs. What Prof. Partridge urges has some relevance to the expansion of technological education in Britain.

The paper by Prof. D. M. Myers on the Australian universities and industry is essentially a factual account of these relations during the past hundred years, which emphasizes the factors dominating the present scene, such as the dependence of the Aus. tralian economy on its primary products, the extreme concentration of the population and of secondary industries in several major centres, and the unusual position in industrial research occupied by government institutions such as the Commonwealth Scientific and Industrial Research Organization. Prof. Myers comments on the unfavourable effect on the universities of this uneven distribution of the population, with the consequent tendency to parochialism and absence of interchange of staff, and he believes that it will be a happy day, too, for Australian industry when the universities regain a proper balance in their activities and are dependent on direct grants through an appropriate body set up for the purpose rather than on the support of a government body established for definite practical objectives. Prof. Myers makes some practical suggestions for future relations between Australian universities and industry on these lines.

Prof. A. Boyce Gibson's paper on the Australien universities and public opinion makes some sound points which should be noted in Britain, though he thinks that, in general, Australian universities have more to learn about public relations from the United States than from Britain. He suggests that the universities should do more to communicate their own scale of values and that the best way to open up public opinion is to do things the use of which is apparent to people uninterested in inquiry and scholarship : in science, by increasing welfare; in arts, by raising the standards of discussion and entertainment.

Prof. R. M. Crawford, discussing postgraduate studies in the non-science faculties, which he suggests are freer than the scientific and technical faculties from the restricting effects of the demand for highly trained professional artisans and research workers, does not believe that research and teaching staffs should be separated, but that more guidance could be offered at the undergraduate stage and that the quality of research rests fundamentally on the quality of the undergraduate schools. He stresses the im- portance of travel and of minimizing professorial administration. Dealing with postgraduate studies in science and engineering, Prof. L. H. Martin also deprecates the tendency in Australia to favour complete segregation of research from teaching and, in particular, to subjugate research and its proper function to the university's responsibility for postgraduate training. In the absence of a background of tradition, the Australian university, he urges, must foster close association with the community which supports it, and here the technological departments have a special responsibility. Prof. Martin is concerned that the average quality of science students has deteriorated in the post-war years. First-class talent is becoming rare among science graduates. There is evidence in Melbourne that the number of Ph.D. candidates in science is likely to decrease, and in 1954 there was only one applicant for the most prized travelling scholarship in science offered within member countries of the British Commonwealth. He also believes that lack of finance, including inadequate salaries, is the fundamental cause of frustration in Australian universities.

\section{UNIVERSITY EDUCATION IN HUNGARY}

$\mathrm{T}$ the eighth university conference organized by the International Association of University Professors and Lecturers and held in Vienna during September 9-14, 1954, Prof. L. Tamas, of the University of Budapest, described the development of university education in Hungary since 1945.

In recent years there has been a vigorous expansion in university education. In the year 1937-38 there were 12,000 students in the universities and the grandes écoles (13 per 10,000 population); in the year 1953-54 there were more than 53,000 such students (56 per 10,000 population). There were 473 foreign students in Hungary, and, with the exception of Australia, all quarters of the world were represented. In 1938-39 Hungary had 16 universities and grandes écoles with 37 faculties; to-day there are 33 universities and grandes écoles with 56 faculties. In 1952 and 1953 the State budget had given almost 260 million forints to the construction of new universities and the expansion of the older institutions.

Prof. Tamas also spoke of student conditions. In former years, the children of workmen and peasants, who formed the greater part of the country's population, represented $3 \frac{1}{2}-4$ per cent of the total number of students; to-day they constitute more than onehalf of the total student body. Women students, to whom all careers are now open, represented 13 per cent of students in 1937-38. To-day the proportion is $26 \frac{1}{2}$ per cent. A noticeable change has taken place in the subjects read. Previously, more than one-half of university students and one-third of the total number of students followed courses in the faculty of law, while those who undertook technical and scientific studies formed much the smallest group. To-day this proportion is reversed : 47 per cent of the total number of students are registered in technical and science faculties, while 3 per cent only follow law courses.

A great deal of State assistance is given to university students. More than three-quarters pay no fees, the remainder pay minimum terminal charges. There are no charges for laboratory-work or examinations. 